\title{
The thymus: when a rudimentary organ becomes active
}

Citation for published version (APA):

Keijzers, M. J. (2015). The thymus: when a rudimentary organ becomes active. [Doctoral Thesis, Maastricht University]. Maastricht University. https://doi.org/10.26481/dis.20150710mk

Document status and date:

Published: 01/01/2015

DOI:

10.26481/dis.20150710mk

Document Version:

Publisher's PDF, also known as Version of record

\section{Please check the document version of this publication:}

- A submitted manuscript is the version of the article upon submission and before peer-review. There can be important differences between the submitted version and the official published version of record.

People interested in the research are advised to contact the author for the final version of the publication, or visit the DOI to the publisher's website.

- The final author version and the galley proof are versions of the publication after peer review.

- The final published version features the final layout of the paper including the volume, issue and page numbers.

Link to publication

\footnotetext{
General rights rights.

- You may freely distribute the URL identifying the publication in the public portal. please follow below link for the End User Agreement:

www.umlib.nl/taverne-license

Take down policy

If you believe that this document breaches copyright please contact us at:

repository@maastrichtuniversity.nl

providing details and we will investigate your claim.
}

Copyright and moral rights for the publications made accessible in the public portal are retained by the authors and/or other copyright owners and it is a condition of accessing publications that users recognise and abide by the legal requirements associated with these

- Users may download and print one copy of any publication from the public portal for the purpose of private study or research.

- You may not further distribute the material or use it for any profit-making activity or commercial gain

If the publication is distributed under the terms of Article $25 \mathrm{fa}$ of the Dutch Copyright Act, indicated by the "Taverne" license above, 
Stellingen behorend bij het proefschrift

\section{The thymus: \\ when a rudimentary organ becomes active}

1. Robotic thymectomy is the optimal approach to perform a complete thymectomy in patients with early stage thymomas. (this thesis)

2. Robotic thymectomy in patients with myasthenia gravis is better tolerated than sternotomy and yields similar clinical results. (this thesis)

3. Additional autoantibodies are not associated with a worse neurological outcome after thymectomy in patients with Myasthenia Gravis. (this thesis)

4. Human Polyomavirus 7 is detected in thymic epithelial tumors by different molecular techniques. (this thesis)

5. International collaborations like the International Thymic Malignancy Interest Group are the cornerstone in the research of orphan diseases.

6. If I had asked people what they wanted, they would have said faster horses. (Henry Ford)

7. If you want something said, ask a man; if you want something done, ask a woman. (Margaret Tatcher)

8. Life is like a box of chocolates. You never know what you're gonna get. (Forrest Gump)

9. Where there is love there is life. (Mahatma Gandhi)

10. De zwezerik is erg lekker in combinatie met peer en mierikswortel. 